Cakrawala Dini: Jurnal Pendidikan Anak Usia Dini | p-ISSN 2087-I317 | e-ISSN 2621-8321 Vol. 9. No.2 November 2018 | Hal 138-147

\title{
PENGEMBANGAN ALAT BERMAIN PAPAN MAGNETIK MAZE UNTUK ANAK
}

\author{
Indah Pratiwi ${ }^{1}$, Syafdaningsih, Rukiyah \\ Program Studi Pendidikan Guru Pendidikan Anak Usia Dini, FKIP, \\ Universitas Sriwijaya
}

\begin{abstract}
This research entitled the development of a magnetic maze board playground for the children group B in Tk Bhakti Asuhahan 1 Palembang whichThis study aims to produce a maze magnetic board play equipment by meeting the valid and practical criteria. This research type is Research Development and developed using a combination of Rowntree development model and Tessmer evaluation. The Rowntree development model consists of three stages, namely the planning, development and evaluation phase. In the evaluation phase, formative evaluation proposed by Tessmer consists of four stages, namely selfevaluation stage, expert review, one-to-one evaluation, and small group evaluation. At the moment the expert review uses material experts and media experts. Oneto-one evaluation stage and Small group is done to the children of kindergarten Bhakti Asuhan 1 Palembang. Technique of collecting data using Walk through with instrument of validation test of material expert and media expert and observation with instrument of observation sheet. Research subjects were 12 children 3 children at One-to-one evaluation stage and 9 children at Small group stage TK Bhakti Asuhan 1 Palembang in the even semester of academic year 2017/2018. Expert review results obtained the average value of the assessment of experts from 3.84 (very valid category). Phase one to one evaluation obtained average child observation result of $86 \%$ (very good category). The small group evaluaion stage obtained the average observation of $92 \%$ (excellent category), From all stages that have been done it can be concluded that the maze magnetic board play equipment declared valid and practical.
\end{abstract}

Keyword: Playground, Magnetic board Maze, 4-5 Years Ages.

\begin{abstract}
Abstrak: Penelitian ini berjudul pengembangan alat bermain papan magnetik maze untuk anak kelompok B TK Bhakti Asuhan 1 Palembang yang bertujuan untuk menghasilkan alat bermain papan magnetik maze dengan memenuhi kriteria valid dan praktis. Jenis penelitian ini Research Development dan dikembangkan menggunakan kombinasi model pengembangan Rowntree dan evaluasi Tessmer. Model pengembangan Rowntree terdiri dari tiga tahap, yaitu tahap perencanaan, pengembangan dan tahap evaluasi. Pada tahap evaluasi dilakukan evaluasi formatif yang dikemukakan oleh Tessmer terdiri dari empat tahap, yaitu tahap self evaluation, expert review, one-to-one evaluation, dan small group evaluation. Pada saat expert review menggunakan ahli materi dan ahli media. Tahap Oneto-one evaluation dan Small group dilakukan pada anak TK Bhakti Asuhan 1 Palembang. Teknik pengumpulan data menggunakan Walkthrough dengan instrumen lembar uji validasi ahli materi dan media serta observasi dengan instrumen lembar observasi . Subjek penelitian adalah 12 anak, 3 anak pada tahap One-to-one evaluation dan 9 anak pada tahap Small group TK Bhakti Asuhan 1 Palembang semester genap tahun ajaran 2017/2018. Hasil expert review diperoleh nilai rata-rata hasil penilaian dari para ahli sebesar 3,84 (kategori sangat valid). Tahap one to one evaluation didapatkan rata-rata hasil observasi anak sebesar $86 \%$ (kategori baik sekali). Tahap small group evaluaion didapatkan hasil rata-rata observasi sebesar $92 \%$ (kategori baik sekali), Dari semua tahap yang telah dilakukan maka dapat disimpulkan bahwa alat bermain papan magnetik maze dinyatakan valid dan praktis
\end{abstract}

Kata Kunci: Alat bermain, Papan magnetik Maze, Anak usia 4-5 Tahun

'Mahasiswa PGPAUD Universitas Sriwijaya, Email: Indahpratiwi950国gmail.com

138 Cakrawala Dini: Vol. 9 No. 2, November 2018 


\section{PENDAHULUAN}

Pendidikan Anak Usia Dini merupakan investasi yang amat besar bagi keluarga dan bangsa yang sangat berharga sekaligus merupakan infra-struktur bagi pendidikan selanjutnya, sebagaimana yang telah ditetapkan dalam Permendikbud No. 146 Tahun 2014 Pasal (1) menyatakan Pendidikan Anak Usia Dini (PAUD), merupakan suatu upaya pembinaan yang ditujukan kepada anak sejak lahir sampai dengan usia 6 tahun yang dilakukan melalui pemberian rangsangan pendidikan untuk membantu pertumbuhan dan perkembangan jasmani dan rohani agar anak memiliki kesiapan dalam memasuki pendidikan lebih lanjut.

Pendidikan Taman Kanak-kanak

(TK) merupakan salah satu bentuk pendidikan formal, pada jalur pendidikan anak usia dini . Di dalam Undang-Undang Sisdiknas nomor 20 tahun 2003 Permendikbud No.137 Tahun 2014 BAB 1 Pasal 1 Ayat (6) dijelaskan standar pendidik dan tenaga kependidikan adalah kriteria tentang kualifikasi akademik dan kompetensi yang dipersyaratkan bagi pendidik dan tenaga kependidikan untuk pendidikan anak usia dini.

Bermain merupakan kebutuhan dan sebagai aktivitas penting yang dilakukan anak-anak.(Holis, 2016; Kusuma, 2016) Menurut Soemiarti yang dikutip oleh Mulyani (2016:84) Bermain merupakan sistem yang digunakan anak untuk memperoleh hasil pemikiran, perasaan serta cara mereka menelusuri dunia lingkungannya. Senada dengan Karl Gros yang dikutip oleh Hasanah dan Pratiwi (2016:7) Mengatakan bahwa bermain mampu memperkuat naluri yang dibutuhkan anak untuk kelangsungan hidupnya dimasa yang akan datang, mengingat dunia anak merupakan dunia bermain, dengan bermain anak mendapatkan pembelajaran dan anak distimulasi untuk berkembang secara umum baik berkembang berpikir, emosi, maupun sosial. Istianti, dkk $(2016 ; 2018)$ mengembangkan model pembelajaran dengan fokus keterampilan sosial kewarganegaraan di tingkat anak usia dini. Selain itu, permainan dengan media pembelajaran juga dapat membantu guru dalam pelajaran Bahasa Inggris (Permana, 2014), IPS (Nisa, 2017), IPA (Marsum, 2015), mengembangkan kemampuan permulaan mengenal huruf (Nafiah, 2016) dan perkembangan motorik anak. (Kusuma, 2016)

Setiap kegiatan yang dilakukan anak hendaknya menarik dan tidak lepas dari unsur bermain, peralatan dan perlengkapan yang diperlukan di dalam bermain hendaknya tersedia dan diutamakan jenis permainan yang dapat mengembangkan semua aspek atau dimensi yang dapat dikembangkan pada diri anak. Guru yang benar mampu mengembangkan semua aspek pada anak dengan berbagai rangsangan, seperti alat permainan maupun peristiwa-peristiwa yang relevan dengan kehidupan anak. Oleh sebab itu tugas guru yang utama sekali yaitu bisa menciptakan alat-alat permainan yang menarik dan menyenangkan bagi anak. (Athiyah, 2016)

Berdasarkan hasil observasi yang dilakukan peneliti, pertama di Tk IT Darussalam Palembang pada bulan Februari 2018 diperoleh informasi dari guru, Ibu Yuliana, alat bermain ada diluar dan didalam,didalam ruangan berupa lego,bola plastik, miniatur binatang serta maze dalam bentuk media buku majalah dengan macam-macam tema. Observasi kedua di Tk Aliyati Palembang pada bulan Februari 2018, penelititi memperoleh informasi dilapangan dari ibu Hikmawati,S.Pd alat bermain yang digunakan didalam ruangan yaitu balok,lego,sempoa,miniatur binatang, plastisin, boneka jari maze bentuk geometri serta maze berupa lember kerja siswa. Observasi ketiga di Tk Bhakti 
Asuhan 1 palembang pada bulan Januari 2018 diperoleh informasi dari ibu Nyimas Fadhilah,S.Pd. alat bermain didalam ruangan yang digunakan berupa, balok, puzzle, lego, kubus angka, tagram, boneka jari dan juga maze berupa lembar kerja anak.

Melalui informasi yang peneliti dapatkan di tiga Taman Kanak-kanak (TK) tersebut permainan Maze memang sering digunakan sebagai alat bantu belajar anak, dan permainan ini termasuk Item klasik yang menjadi wajib untuk disetiap sekolah, namun media maze yang terdapat di tiga $\mathrm{Tk}$ tersebut rata-rata berbentuk lembar kerja anak (LKA) yang hanya bisa dikerjakan satu kali dengan menggunakan media alat tulis, kemudian waktu dalam mengerjakannya sangat cepat sehingga pembelajaran yang diberikan mudah dilupakan oleh anak, maka dari itu peneliti ingin mengembangkan alat bermain berupa papan magnetik berbentuk maze bertema Rekreasi yang dapat memacu rasa ingin tahu anak karna terlihat seperti miniatur sehingga pembelajaran yang diberikan lebih bermakna bagi anak-anak yang efektif dan layak digunakan bisa dimainkan berulang-ulang yang sesuai dengan karakteristik anak usia 5-6 Tahun.

Menurut hasil Penelitian yang dilakukan oleh Permana (2014) yaitu "Pengembangan Media Kartu Bergambar Magnetik Pada Mata Pelajaran Bahasa Inggris Materi Pokok Penguasaan Kosakata Pada Kelas II SDN Mojosari".Vol.1 No,1 2014. Hasil uji validasi kelanyakan media kartu bergambar magnetik oleh ahli materi I dengan 3,73 kategori sangat baik, ahli materi II dengan 3,78 kategori sangat baik, ahli media I dengan 3,8 dengan kategori sangat baik, ahli media II dengan 3,83 kategori sangat baik, angket siswa dengan 89,29 kategori sangat baik. Berdasarkan hasil belajar siswa pada penggunaan media kartu bergambar diperoleh d.b $=\mathrm{N}-1=31-1=30$ dengan taraf kesalahan 5\% $(0,05)$ adalah 2,04 dan t-hitung adalah 10,4. Apabila t-tabel $<\mathrm{t}$ hitung, maka 2,04<8,69. Sehingga dapat disimpulkan terdapat pengaruh yang signifikan dalam penggunaan media kartu bergambar magnetik terhadap kemampuan siswa dalam penguasaan kosa kata bahasa Inggris kelas II SDN Mojosari Kab. Mojokerto.

Berdasarkan permasalahan diatas, pengembangan alat bermain papan magnetik maze merupakan hal yang penting.mengacu pada permasalahan tersebut penelitian ini dituliskan pada "Pengembangan Alat Bermain Papan Magnetik Maze Untuk Anak Kelompok B di Tk Bhakti Asuhan 1 Palembang".

\section{METODOLOGI PENELITIAN}

\section{Jenis Penelitian}

Jenis penelitian yang diambil oleh peneliti adalah jenis penelitian pengembangan (Research Development). Menurut Sugiyono (2015):407) Metode penelitian dan pengembangan adalah metode penelitian yang digunakan untuk menghasilkan produk tertentu, dan menguji keefektifan produk tersebut. Untuk dapat menghasilkan produk tertentu digunakan penelitian yang bersifat analisis kebutuhan dan untuk menguji kefektifan produk tersebut supaya dapat berfungsi di masyarakat luas, maka diperlukan penelitian untuk menguji keefektifan produk tersebut.

Subjek dalam penelitian ini alat permainan edukatif dan objek dalam penelitian ini adalah anak kelompok B TK Bhakti Asuhan 1 palembang. Objek dalam penelitian ini adalah Alat bermain papan magnetik maze yang melalui tahap uji coba one-to-one 3 anak, small group 9 anak.

Penelitian ini dilakukan di TK Bhakti Asuhan 1 Jln. Ariodillah Komplek Perumahan No.4551 Palembang untuk anak kelompok B semester genap tahun ajaran 2017-2018.

\section{Prodedur Penelitian}

Prosedur penelitian pengembangan ini untuk menghasilkan dan menguji produk 
menggunakan model Rowntree dalam mengembangkan media pembelajaran. Prosedur penelitian ini menggunakan 3 tahap sebagai berikut.

Tahap Perencanaan, Pada tahap ini dilakukan analisis kebutuhan dan kebutuhan perkembangan dilakukan untuk mengetahui dan mengidentifikasi perkiraan kebutuhan dan perkembangan anak, yaitu dengan melihat karakteristik dan indikator pencapaian perkembangan anak usia 5-6 tahun dan mendeskripsikan kriteria media yang baik untuk anak desesuaikan dengan tema yang ada dikurikulum.

Tahap Pengembangan, pada tahap ini peneliti mengembangkan desain dan materi yaitu materi merupakan penentuan isi pembelajaran pada Alat bermain papan magnetik maze. Materi harus sesuai dengan kebutuhan anak dan target yang akan dicapai oleh peneliti adalah penguasaan pembelajaran Tema Rekreasi Sub tema Kebun binatang dalam bentuk papan magnetik maze untuk anak usia 5-6 tahun setelah menggunakan Alat bermain papan magnetik maze.

Garis besar materi pembelajaran dijadikan dasar untuk merancang desain Alat Bermain papan magnetik maze yaitu sebagai berikut. (1) Konsep desain gambar, pada konsep desain maze peniliti membuat dua alur maze kemudian peneliti meminta pendapat kepada teman sejawat untuk membantu memilih salah satu desain alur maze yang sesuai dengan karakteristik anak kelompok B kemudian selanjutnya peneliti dibantu oleh kak diah purnamasari dalam pembuatan desain menggunakan aplikasi CorelDraw X8. (2) Desain kemasan media, untuk kemasan media peniliti dibantu oleh kak rizky dalam pembuatannya yang menggunakan bahan kayu meranti yang didesain seperti meja lipat berbentuk segi empat dengan tebal $3 \mathrm{~cm}$ pada bagian bawah dan segi empat pada bagian atas yang bahannya menggunakan kayu triplek tipis untuk alasnya fungsinya agar kedua magnet bisa direkatkan, namun ukurannya lebih besar dari bagian bawah agar gambar miniatur bisa di simpan didalamnya .

\section{Evaluasi}

Pada tahap ini, prototipe 1 hasil desain awal akan dievaluasi dengan mengikuti prosedur evaluasi formatif dari Tessmer dengan langkah-langkah sebagai berikut.

Tahap Self Evaluation Pada tahap ini penilaian dilakukan oleh peneliti sendiri terhadap produk berupa alat bermain papan megnetik maze yang telah dikembangan. Disini peneliti mengevaluasi sendiri dan peneliti juga meminta saran teman sejawat untuk melakukan penilain pada produk yang akan dikembangkan, apakah bentuknya sudah sesuai dan jelas, dari segi warna menarik dan apakah sesuai dengan konsep pembelajaran untuk anak usia 5-6 tahun.

Tahap Expert Review, Hasil produk (prototipe 1) yang dikembangkan atas dasar Self Evaluation, diberikan kepada para ahli (expert) untuk validasi.pada tahap ini validator melihat dam mengevaluasi desain ketiga produk yang telah dibuat. Uji validitas yang dilakukan adalah uji validitas materi dan desain Alat Bermain. Hasil validasi yang berupa tanggapan/komentar dan saran-saran pada lembar validasi akan dijadikan dasar untuk merevisi Alat Bermain Papan Magnetik Maze (prototipe 1).

Tahap One-to-one Evaluation, Pada tahap ini, ketiga produk alat bermain papan magnetik maze diujicobakan pada anak. Peneliti memilih tiga orang anak secara acak untuk mewakili populasi target yaitu anak dengan kemampuan rendah, sedang, dan tinggi. Anak tersebut diberikan pembelajaran dengan prototipe 1 yang sudah direvisi. Pada saat proses pembelajaran anak akan diobservasi melalui lembar observasi yang telah disediakan untuk melihat dan menilai secara langsung tingkah laku atau proses terjadinya suatu pembelajaran dengan menggunakan prototipe 1 . Hal ini dilakukan dengan tujuan untuk melihat kepraktisan alat bermain tersebut dari sudut pandang anak. Hasil observasi anak tersebut akan dijadikan dasar untuk merevisi produk (prototipe 1) sehingga menghasilkan prototipe 2

Tahap Small Group Evaluation, Pada tahap ini prototipe 2 diujicobakan pada small group yang terdiri dari 9 orang anak TK BHAKTI ASUHAN 1 PALEMBANG yang memiliki kemampuan berbeda. Selanjutnya, anak diberikan pembelajaran dengan prototipe 2 yang sudah direvisi. Pada proses pembelajaran, anak akan diobservasi kembali untuk melihat dan menilai secara langsung tingkah laku atau proses terjadinya suatu 
pembelajaran dengan menggunakan alat bermain papan magnetik maze (prototipe 2) yang digunakan. Melalui hasil observasi pada tahap ini apa bila masih ada kekurangan pada produk yang sedang peneliti kembangkan di revisi kembali sehingga menjadi produk yang telah teruji kepraktisannya.

\section{Teknik Pengumpulan Data}

Adapun teknik pengumpulan data yang digunakan dalam penelitian ini adalah Waltrought, Wawancara dan Observasi. Walkthrough dikutip Anggraini (2015) adalah validasi data yang melibatkan beberapa ahli untuk mengevaluasi produk sebagai dasar untuk merevisi produk awal/prototipe 1. Instrumen pengumpul data pada teknik ini adalah dengan menggunakan lembar validasi yang diberikan kepada ahli atau validator. Data yang dikumpulkan pada lembar validasi ini adalah berupa tanggapan dan saran-saran yang menjadi dasar peneliti untuk melakukan revisi pada produk awal/prototipe. Data dari hasil validasi oleh ahli kemudian didiskusikan dengan ahli itu sendiri untuk mendapatkan kejelasan informasi hasil validasi produk, sehingga peneliti bisa menggunakan data hasil validasi tersebut sebagai acuan untuk merevisi produk/prototipe sampai dinyatakan layak untuk diujicobakan. Dalam Alat Bermain Papan Mahnetik Maze, proses validasi ahli meliputi validasi materi dan media. Adapun kisi-kisi intrumen validasi materi dan media dapat dilihat pada Tabel 3.1 dan 3.2 di bawah ini.

Tabel 1 Kisi-kisi instrumen validasi content/materi

\begin{tabular}{|l|l|l|}
\hline No & Indikator & Item \\
\hline 1 & $\begin{array}{l}\text { Kriteria Materi Pada } \\
\text { Media }\end{array}$ & $1,2,3,4$ \\
& $\begin{array}{l}\text { Kesesuain dengan } \\
\text { pembelajaran anak } \\
\text { usia 5-6 tahun } \\
\text { Kesesuaian dengan } \\
\text { kebutuhan dan } \\
\text { perkembangan anak } \\
\text { usia 5-6 tahun } \\
\text { Manfaat Media }\end{array}$ & 9,10,11,12 \\
4
\end{tabular}

Tabel 2 Kisi-kisi instrumen validasi Meida/desain

\begin{tabular}{|l|l|l|}
\hline No & Indikator & Item \\
\hline 1 & Kualitas Alat & $1,2,3,4$ \\
2 & Bermain & $5,6,7,8$, \\
& Tampilan Alat & \\
3 & Bermain & $9,10,11,12$ \\
& Keamanan Alat & $13,14,15,16$ \\
4 & Bermain & \\
& Ilustrasi Alat & \\
& Bermain & \\
\hline
\end{tabular}

Teknik pengumpulan data yang kedua adalah observasi. menurut Sugiyono (2015: 203) Observasi digunakan untuk menilai tingkah laku dilihat dari keaktifan anak pada kegiatan pembelajaran dengan menggunakan Alat bermain papan magnetik maze yang dapat diamati. Pada penelitian ini, untuk mendapatkan data observasi dilakukan dengan cara melihat dan menilai secara langsung aktivitas dan tingkah laku anak selama proses pembelajaran dengan menggunakan alat bermain papan magnetik maze. Observasi dilakukan pada saat tahap One-to-one dan small group apakah sudah terlaksana dengan baik saat menggunakan alat bermain papan magnetik maze. Hasil observasi dicatat oleh peneliti pada lembar observasi yang telah disediakan dengan kisi-kisi yang dapat dilihat pada Tabel 3.3 dibawah ini.

Tabel 4 Kisi-Kisi Instrumen Observasi Penilaian Aktivitas Anak Terhadap Penggunaan Alat Bermain Papan Magnetik Maze

\begin{tabular}{|l|l|c|}
\hline No & \multicolumn{1}{|c|}{ Indikator Kegiatan } & Nomor \\
\hline 1 & $\begin{array}{l}\text { Memperlihatkan } \\
\text { kemampuan Mampu } \\
\text { memecahkan sendiri } \\
\text { masalah sederhana yang } \\
\text { dihadapi }\end{array}$ & 1 \\
\hline 2 & $\begin{array}{l}\text { Melakukan proses kerja } \\
\text { sesuai dengan prosedurnya }\end{array}$ & 2 \\
\hline 3 & $\begin{array}{l}\text { Menggunakan anggota } \\
\text { tubuh untuk mengem } \\
\text { bangkan motorik kasar dan } \\
\text { halus }\end{array}$ & 3 \\
\hline 4 & $\begin{array}{l}\text { Menunjukan kemampuan } \\
\text { berbahasa ekspresif }\end{array}$ & 4 \\
\hline
\end{tabular}




\begin{tabular}{|l|l|l|}
\hline $\begin{array}{l}\text { (mengungkap kan bahasa } \\
\text { secara verbal dan non } \\
\text { verbal) }\end{array}$ & \\
\hline \multicolumn{1}{|c|}{ (Permen No. 146 Tahun 2014) }
\end{tabular}

Hasil Walkthrough dengan ahli dianalisis secara deskriptif sebagai masukan untuk merevisi alat bermain. Masukan tersebut dituliskan pada lembar validasi. Lembar validasi yang diberikan kepada ahli dalam bentuk skala likert. Sugiyono (2015: 135) Skala Likert dengan menggunakan empat kategori jawaban yaitu sangat Baik (SB), Baik (B), Tidak Baik (TB), dan Sangat Tidak Baik (STB). Seperti yang terlihat pada Tabel 5 berikut.

Tabel 5 Kategori Nilai Validasi

\begin{tabular}{|l|c|}
\hline Kategori Jawaban & Skor Pernyataan \\
\hline Sangat Baik & 4 \\
Baik & 3 \\
Tidak Baik & 2 \\
Sangat Tidak & 1 \\
Baik & \\
\hline
\end{tabular}

(Modifikasi Sugiyono, 2015:135)

Hasil validasi dari validator disajikan dalam bentuk tabel. Selanjutnya dicari rata-rata skor tersebut dengan menggunakan rumus sebagai berikut.

$$
\mathrm{x}=\frac{\sum X}{N}
$$

(Sudjana, 2017: 109)

Ket :

$\mathrm{X}=$ Nilai rata-rata

$\sum X=$ Jumlah nilai data

$\mathrm{N} \quad=$ Banyaknya data

Selanjutnya rata-rata yang didapatkan disesuaikan dengan kategori seperti yang terlihat pada Tabel 3.5 berikut ini

Tabel 6 Kategori Tingkat Kevalidan

\begin{tabular}{cc}
\hline Rata-Rata & Kategori \\
\hline $3,25-4,00$ & Sangat Valid \\
$2,50-3,24$ & Valid \\
$1,75-2,49$ & Tidak Valid \\
\hline
\end{tabular}

\begin{tabular}{cc}
\hline $1,00-1,74$ & Sangat Tidak \\
Valid
\end{tabular}

Hasil observasi terhadap anak selama ujicoba pada tahap One-to-one evaluatio dan small group evaluation digunakan untuk melihat tingkah laku anak pada saat proses pembelajaran menggunakan alat bermain papan magnetik maze ini. Data hasil observasi dengan menggunakan rumus sebagai berikut.

$$
\begin{aligned}
& \text { Nilai Persentase } \\
& =\frac{\text { Skor Perolehan }}{\text { Skor Maksimal }} \times 100 \%
\end{aligned}
$$

(Sunarti \& Rahmawati, 2014: 191)

Nilai observasi dikonversikan ke dalam kategori yang ditetapkan seperti pada Tabel 7 di bawah ini.

Tabel 7 Kategori Nilai Hasil Observasi Anak Terhadap Penggunaan Alat Bermain Papan Magnetik Maze

\begin{tabular}{|l|l|}
\hline \multicolumn{1}{|c|}{ Skor (\%) } & \multicolumn{1}{c|}{ Kategori } \\
\hline $80-100$ & Baik Sekali \\
$70-79$ & Baik \\
$60-69$ & Cukup \\
$<60$ & Kurang \\
\hline \multicolumn{2}{|c|}{ (Amirono \& Daryanto, 2016: 126) } \\
\hline
\end{tabular}

\section{HASIL PENELITIAN DAN PEMBAHASAN}

Analisis kebutuhan dan perkembangan dilakukan untuk mengetahui dan mengidentifikasi perkiraan kebutuhan dan perkembangan anak, pertama peneliti meninjau langsung di Taman Kanak-kanak yaitu Tk Bhakti Asuhan 1 Palembang peneliti memperoleh informasi dari ibu Nyimas Fadhilah,S.Pd bahwa pembelajaran yang diberikan terlalu sering menulis dan mewarnai sehingga anak merasa bosan dan lelah untuk mengerjakan tugasnya, ketika peneliti bertanya pembelajaran apa yang 
digemari anak ,menurut ibu nyimas salah satu pembelajaran yang digemari anak adalah tentang maze anak-anak selalu antusias dalam mengerjakannya namun pembelajaran maze yang diberikan dalam bentuk buku juga yang dikerjakan menggunakan alat tulis, dari hasil analisis kebutuhan peneliti pendapatkan ide untuk mengembangkan alat bermain papan magnet berbentuk maze yang bisa menimbulkan rasa ingin tahu anak, alat tersebut didesain menggunakan tema rekreasi sub tema kebun binatang gunanya untuk mempersingkat waktu tetapi tujuannya sama yaitu untuk menambah pengetahuan anak dengan cara pratis yang medianya menyerupai replika yang sesungguhnya dan bisa dibongkar pasang serta dimainkan berulang-ulang. Ibu nyimas mengatakan bahwa alat yang akan dikembangkan oleh peneliti dibutuhkan di Tk Bhakti Asuhan 1 karena dengan alat tersebut anak bisa belajar sekaligus sambil bermain. Selanjutnya peneliti menganalisis kembali kedua Tk yaitu Tk IT Darussalam dengan ibu Yuliana dan Tk Aliyati dengan ibu Hikmawati hasil wawancara yang didapatkan senada dengan hasil awancara di Tk Bhakti Asuhan 1 bahwa kedua tk tersebut menggunakan maze pada pembelajaran dalam bentuk buku lembar kerja anak, kedua Tk ini membutuhkan alat peraga yang dikembangkan oleh peneliti untuk menambah sarana bermain anak karena bisa dipraktikan secara langsung dan tentunya agar anak tidak mudah bosan selain itu juga penentuan temanya bagus karena tema tersebut jarang digunakan dalam bentuk alat peraga di taman kanakkanak tersebut.

Langkah selanjutnya adalah pengembangan materi dan media produk Adapun materi yang diberikan pada anak yaitu pembelajaran dengan tema rekreasi sub tema kebun binatang sesuai yang ada di kurikulum 2013 untuk anak kelompok B, yaitu dalam bentuk gambar lingkungan yang ada disekitar kebun binatang dari gambar tersebut anak dapat menghitung jumlah hewan yang ada dikebun binatang, mengkomunikasikan apa saja yang ada ditempat rekreasi tersebut, memecahkan masalah sederhana bermain maze magnet dengan menggerakkan dan mencocokan gambar hewan sesuai dengan tempat hidupnya, Garis besar materi pembelajaran dijadikan dasar untuk merancang desain Alat Bermain papan magnetik maze yaitu sebagai berikut. (1) Konsep desain gambar, pada konsep desain maze peniliti membuat dua alur maze kemudian peneliti meminta pendapat kepada teman sejawat untuk membantu memilih salah satu desain alur maze yang sesuai dengan karakteristik anak kelompok B kemudian selanjutnya peneliti dibantu oleh kak diah purnamasari dalam pembuatan desain menggunakan aplikasi CorelDraw X8. (2) Desain kemasan media, untuk kemasan media peniliti dibantu oleh kak rizky dalam pembuatannya yang menggunakan bahan kayu meranti yang didesain seperti meja lipat berbentuk segi empat dengan tebal $3 \mathrm{~cm}$ pada bagian bawah dan segi empat pada bagian atas yang bahannya menggunakan kayu triplek tipis untuk alasnya fungsinya agar kedua magnet bisa direkatkan, namun ukurannya lebih besar dari bagian bawah agar gambar miniatur bisa di simpan didalamnya.Format kertas yang digunakan adalah portrait. Menggunakan kertas A3 Ukuran gambar desain maze yang digunakan yaitu $30 \times 32$ $\mathrm{cm}$ dan gambar replika hewan yang ukurannya disesuaikan, dengan menggunakan jenis kertas laser stiker $P V C$ atau stiker Vinyl yang terbuat dari bahan Vinyl atau sejenis plastik, stiker ini kuat dan tahan air dan tidak bisa disobek.

Setelah merancang konsep desain, langkah selanjutnya adalah produksi prototipe. konsep desain yang telah dibuat disesuaikan dengan materi pembelajaran anak kelompok B. Peneliti memproduksi 3 produk berupa Alat Bermain Papan Magnetik Maze dengan Tema Rekreasi dan sub tema kebun binatang. Hasil keseluruhan tahap Pengembangan ini adalah prototipe 1 . Pada tahap Pengembangan juga disiapkan alat evaluasi yang digunakan untuk menilai 
Alat Bermain yang telah dibuat dilihat dari segi materi dan media.

Dari konsep yang telah divisualisasikan dalam bentuk Alat Bermain Papan Magnetik Maze yang dilengkapi gambar dan telah didesain disebut prototipe 1. Selanjutnya prototipe 1 dilakukan tahap self evaluation. Pada tahap ini peneliti mengevaluasi produk sendiri dan juga meminta saran dan kritik dari teman-teman sejawat dan orang tua. Setelah self evaluation dilakukan kemudian lanjut ke tahap expert review yang terdiri dari ahli materi dan ahli media. Selain itu, dilakukan uji coba one-to-one evaluation pada 3 orang anak kelompok B, small group evaluation pada 9 orang anak kelompok B. Hasil dari masing-masing tahap evaluasi sesuai dengan model evaluasi formatif Tessmer yaitu sebagai berikut.

Expert Review merupakan tahap untuk melihat validitas secara materi dan media dengan materi pembelajaran yang dikembangkan oleh peniliti. Tahap ini bertujuan untuk mendapat materi dan media yang valid. Para pakar/ahli yang menjadi validator prototype 1 adalah : (1) Dra.Hasmalena, M.Pd Dosen Universitas Sriwijaya.Sebagai validator media. (2) Mahyumi Rantina,M.Pd Dosen Universitas Sriwijaya.Sebagai validator materi. Hasil penilaian validator materi dapat dilihat pada Tabel 8 berikut ini.

Tabel 8 Hasil Penilaian Validator Content/Materi

\begin{tabular}{|c|l|c|c|c|}
\hline No & Indikator & $\begin{array}{c}\text { Nomor } \\
\text { Pernyata } \\
\text { an }\end{array}$ & $\begin{array}{c}\text { Jumlah } \\
\text { Pernyata } \\
\text { an }\end{array}$ & $\begin{array}{c}\text { Rekapitulasi } \\
\text { Nilai }\end{array}$ \\
\hline 2 & $\begin{array}{l}\text { Kriteria } \\
\text { materi pada } \\
\text { media } \\
\text { Kesesuaian } \\
\text { dengan } \\
\text { pembelajara } \\
\text { n anak usia } \\
5-6 \text { tahun }\end{array}$ & $1,2,3,4$ & 4 & 15 \\
\hline
\end{tabular}

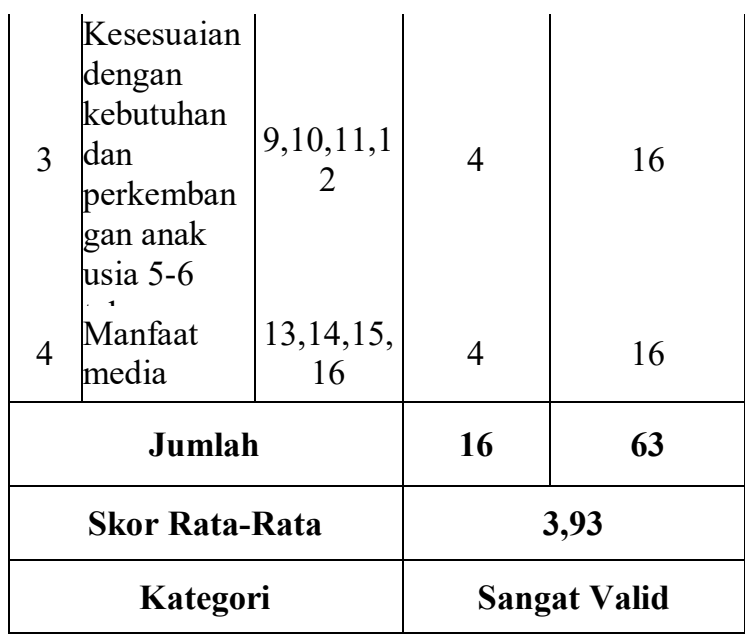

Tabel 9 Tabel Hasil Penilaian Validator Desain

\begin{tabular}{|c|c|c|c|c|}
\hline No & $\begin{array}{c}\text { INDIKAT } \\
\text { OR }\end{array}$ & $\begin{array}{c}\text { Nomor } \\
\text { Pernyataa } \\
\text { n }\end{array}$ & $\begin{array}{c}\text { Jumlah } \\
\text { Pernyata } \\
\text { an }\end{array}$ & $\begin{array}{c}\text { Rekapitu } \\
\text { lasi } \\
\text { Nilai }\end{array}$ \\
\hline 1 & $\begin{array}{l}\text { Pewarnaan } \\
\text { media }\end{array}$ & $1,2,3,4$ & 4 & 15 \\
\hline 2 & $\begin{array}{l}\text { Kemasan } \\
\text { media }\end{array}$ & $5,6,7,8$ & 4 & 15 \\
\hline 3 & $\begin{array}{l}\text { Pemakaian } \\
\text { media }\end{array}$ & $9,10,11,12$ & 4 & 16 \\
\hline 4 & $\begin{array}{l}\text { Desain } \\
\text { media }\end{array}$ & $13,14,15,16$ & 4 & 14 \\
\hline \multicolumn{3}{|c|}{ Jumlah } & 16 & 60 \\
\hline \multicolumn{3}{|c|}{ Skor Rata-Rata } & \multicolumn{2}{|c|}{3,75} \\
\hline \multicolumn{3}{|c|}{ Kategori } & \multicolumn{2}{|c|}{ Sangat Valid } \\
\hline
\end{tabular}

Tabel 10 Rekapitulasi Hasil Penilaian Validator

\begin{tabular}{|c|c|c|}
\hline No & Validasi & Rekapitulasi Nilai \\
\hline 1 & Content/materi & 3,93 \\
2 & Desain & 3,75 \\
\hline \multicolumn{2}{|c|}{ Rata-Rata } & $\mathbf{3 , 8 4}$ \\
\hline & Kategori & Sangat Valid \\
\hline
\end{tabular}

Dengan demikian, alat bermain papan magnetik maze yang dikembangkan ini layak untuk diuji coba dengan beberapa komentar dan saran dari validator. 
Tabel 11 Data hasil observasi anak Pada tahap One to One

\begin{tabular}{|c|c|l|c|}
\hline No & Nama & \multicolumn{1}{|c|}{ Indikator } \\
\cline { 3 - 4 } & & $\begin{array}{l}\text { 1. Merangkai Alat Bermain } \\
\text { papan magnetik maze } \\
\text { 2. Menyebutkan apa saja yang } \\
\text { ada di tempat rekreasi "kebun } \\
\text { binatang" } \\
\text { 3. Menghitung jumlah replika } \\
\text { hewan } \\
\text { 4. Mengerjakan tugas maze } \\
\text { menunjukan jalan hewan } \\
\text { menuju tempat tinggalnya }\end{array}$ \\
\cline { 3 - 4 } & AR & Skor & Nilai \\
\hline 1 & 13 & 81 \\
\hline 2 & HS & 15 & 93 \\
\hline 3 & MH & 14 & 87 \\
\hline Jumlah & & 261 \\
\hline Rata-rata & & $87 \%$ \\
\hline
\end{tabular}

Hasil Nilai persentase rata-rata hasil observasi anak terhadap pengunaan Alat Bermain Papan Magnetik Maze pada tahap one-to-one evaluation sebesar $85 \%$ (kategori baik sekali). Senada dengan penelitian yang dilakukan oleh Marsum (2016) bahwa pada tahap one-to-one didapat skor akhir kepraktisan 3,09 (praktis), sehingga dapat disimpulkan bahwa penggunaan Alat bermain papan magnetik maze memiliki kriteria praktis bagi anak. Berdasarkan validasi ahli dan observasi anak, prototipe 1 direvisi menjadi prototipe 2 yang selanjutnya akan diujicobakan pada tahap small group evaluation.

Tabel 12 Data hasil observasi anak Pada tahap Small Group

\begin{tabular}{|c|c|c|c|}
\hline \multirow[t]{3}{*}{ No } & \multirow[t]{3}{*}{ Nama } & Indikatc & \\
\hline & & \multicolumn{2}{|c|}{$\begin{array}{l}\text { 1. Merangkai Alat Bermain } \\
\text { papan magnetik maze } \\
\text { 2. Menyebutkan apa saja yang } \\
\text { ada di tempat rekreasi "kebun } \\
\text { binatang" } \\
\text { 3. Menghitung jumlah replika } \\
\text { hewan } \\
\text { 4. Mengerjakan tugas maze } \\
\text { menunjukan jalan hewan } \\
\text { menuju tempat tinggalnya }\end{array}$} \\
\hline & & Skor & Nilai \\
\hline 1 & RP & 16 & 100 \\
\hline
\end{tabular}

\begin{tabular}{|c|c|c|c|}
\hline 2 & GAC & 14 & 87 \\
\hline 3 & HB & 14 & 87 \\
\hline 4 & MZA & 16 & 100 \\
\hline 5 & KNA & 12 & 75 \\
\hline 6 & HK & 15 & 93 \\
\hline 7 & RF & 16 & 100 \\
\hline 8 & FP & 14 & 87 \\
\hline 9 & NA & 16 & 100 \\
\hline Jumlah & 829 \\
\hline \multicolumn{2}{|l|}{ Rata-rata } & $92 \%$ \\
\hline
\end{tabular}

Pada tahap small group evaluation, prototipe 2 diujicobakan kepada 9 orang anak secara kelompok. Pada akhir uji coba small group evaluation, anak diobservasi kembali keaktifannya terhadap prototipe 2 yang sedang dikembangkan. Hasil observasi anak terhadap penggunaan alat bermain papan magnetik maze dapat dilihat pada Tabel 4.7 Analisis data observasi anak pada tahap Small Group Evaluation yang memiliki 4 indikator yaitu, (1) Merangkai Alat Bermain papan magnetik maze, (2) Menyebutkan apa saja yang ada di tempat rekreasi "kebun binatang", (3) Menghitung jumlah replika hewan, (4) Menunjukan jalan hewan menuju tempat tinggalnya diperoleh Nilai persentase rata-rata hasil observasi anak terhadap pengunaan Alat bermain papan magnetik maze pada tahap small group evalation sebesar $92 \%$ (kategori baik sekali), sehingga dapat disimpulkan bahwa penggunaan Alat bermain papan magnetik maze memiliki kriteria praktis bagi anak.

\section{KESIMPULAN}

Berdasarkan penelitian yang telah dilakukan tentang pengembangan alat bermain papan magnetik maze dapat disimpulkan sebagai berikut.Alat bermain papan magnetik maze yang dikembangkan dinyatakan sangat valid berdasarkan hasil validasi para ahli (expert review) yang terdiri dari ahli materi dan desain sehingga alat bermain papan magnetik maze ini layak digunakan. Hal ini dapat diketahui dari rata-rata hasil expert review sebesar 3,90 (kategori sangat valid).

Untuk menguji kepraktisan alat bermain papan magnetik maze dilihat dari 
kemudahan dalam menggunakannya. Berdasarkan hasil tahap one-to-one evaluation sebesar 86\% (kategori baik sekali) diperoleh nilai observasi anak terhadap penggunaan buku cerita matematika. Berdasarkan hasil nilai observasi anak terhadap penggunaan alat bermain papan magnetik maze pada tahap small group evaluation mendapatkan ratarata pada 4 sebesar 92\% (kategori baik sekali) sehingga berdasarkan hasil one-toone evaluation dan small group evaluation dapat dinyatakan bahwa buku cerita matematika yang dikembangkan telah teruji praktikalitasnya

\section{DAFTAR PUSTAKA}

Anggraini. (2015). Pengembangan Media Layanan Klasikal Berbasis Cerita Bergambar Bidang Sosial-Pribadi dengan Materi Kesetiakawanan Sosial di Kelas IV SD Negeri 179 Palembang. Skripsi. Inderalaya: Universitas Sriwijaya.

Athiyah,Ummu.(2016). Pengembangan Alat Permainan Maze "Papan Laju Warna" Untuk Menstimulasi Kesiapan Membaca Anak Kelompok B Di Tk Aba As-Salam. Jurnal Prodi Teknologi Pendidikan 5(8): 1-8.

Holis, Ade. (2016). Belajar Melalui Bermain Untuk Pengembangan Kreativitas dan Kognitif Anak Usia Dini. Jurnal pendidikan Universitas Garut. 9(1): 23-37.

Hasan,R.O. Meningkatkan Kemampuan Mengenal Huruf Hijaiyah Melalui Media Papan Magnet pda Anak Tunagrahita Sedang Kelas VI SLB Karya Padang. Jurnal Ilmiah pendidikan khusus. 5(2): 115-125.

Hestari,Selvira dkk.(2016) .Validitas Kepraktisan ,Dan Efektivitas Media Pembelajaran Magnetik Pada Materi Mutasi Gen.Jurnal pendidikan biologi. 5(1): $1-7$

Istianti, T., Abdillah, F., \& Hamid, S. I. (2018). Model Pembelajaran Perilaku Sosial Kewarganegaraan: Upaya Guru Dalam Memupuk Gotong Royong
Sejak Dini. Cakrawala Dini: Jurnal Pendidikan Anak Usia Dini, 9(1), 5662.

Istianti, T., Hamid, S. I., \& Abdillah, F. Ulfah.(2016). Menelisik Nilai Moral Sosial Kewarganegaraan dalam Permainan Anak Usia Dini. Jurnal Moral Kemasyarakatan, 1(2), 86-96.

Kusuma,A.G \& Sudarmilah,E. (2016). Pengembangan Permainan Labirin utuntu Membantu Perkembangan Motorik Anak. Jurnal ilmiah tekni elektro. 3(2):46-89.

Marsum.(2015)."Pengembangan Media Pembelajaran Ipa Berbasis Stop Motion Pada Materi Gaya Magnet Dikelas V SD Negeri 05 Inderalaya". Fakultas keguruan dan ilmu pendidikan,Universitas sriwijaya.Palembang.

Nafiah,Umi.(2016). Mengembangkan Kemampuan Permulaan Mengenal Huruf Melalui Media Papan Magnet Pada Anak Usia Dini Di Kb Bina Bangsa. Jurnal pendidikan 1(1): 1-17.

Nisa,A.C.(2017). Pengembangan Media Papan Magnet Sumberdaya Alam Diy Mata Pelajaran Ips Kelas IV Di Sdn Minomartani 6 Ngaglik Sleman.Jurnal pendidikan guru sekolah dasar.

Permana,D.R.I.K. (2014). Pengembangan Media Kartu Bergambar Magnetik Pada Mata Pelajaran Bahasa Inggris Materi Pokok Penguasaan Kosakata Pada Kelas Ii SDN Mojosari. Jurnal pendidika. 1(1): 1-10. 